\title{
Surface accumulation on Foundation Ice Stream, Antarctica
}

\author{
Wolfgang Graf, ${ }^{1}$ Oskar Reinwarth, ${ }^{2}$ Hans Oerter, ${ }^{3}$ Christoph Mayer, ${ }^{3}$ Astrid Lambreght ${ }^{3}$ \\ ${ }^{1}$ GSF-Forschungszentrum für Umwelt und Gesundheit, Postfach 1129, D-85758 Neuherberg, Germany \\ ${ }^{2}$ Bayerische Akademie der Wissenschaften, Kommission für Glaziologie, Marstallplatz 8, D-80539 München, Germany \\ ${ }^{3}$ Alfred Wegener Institute for Polar and Marine Research, P.O. Box 120161, D-27515 Bremerhaven, Germany
}

\begin{abstract}
This paper presents new data, derived from an analysis of 16 firn cores, on the distribution of the accumulation rate and ${ }^{18} \mathrm{O}$ content of near-surface layers in the eastern part of the Ronne Ice Shelf, Antarctica. The firn cores were drilled along the traverse route of the Filchner-V-Campaign in 1995. The traverse followed an ice flowline of the Foundation Ice Stream and reached the margin of the inland ice, an area which has not yet been investigated. On the ice shelf the accumulation rates decrease with distance from the coast. Ascending to the inland ice the accumulation rates again reach almost coastal values. This regional distribution is in agreement with the temperature gradient along the traverse. The ${ }^{18} \mathrm{O}$ content of the near-surface layers is closely related to the $10 \mathrm{~m}$ firn temperature. They strongly decrease from the grounding line towards the inland ice. At the southernmost site at $1100 \mathrm{~m}$ a.s.l., the mean $\delta^{18} \mathrm{O}$ value of the firn decreases to $-40 \%$. Ice with that isotopic signature was found in cores from the central part of the Ronne Ice Shelf just above the marine ice layer, indicating that it originates from this area. All ice deposited as snow further south was melted beneath the ice shelf after passing the grounding-line area. The time series of accumulation rate and ${ }^{18} \mathrm{O}$ content reveal no climatic trend during the last $30-50$ years.
\end{abstract}

\section{INTRODUCTION}

In 1995 the Filchner-V-Campaign set out to investigate the mass balance of the area around the grounding line of the Ronne Ice Shelf where two important ice streams, the Foundation Ice Stream and the Möllereisstrom, drain into the ice shelf. Results of mass-balance studies, especially concerning melting rates beneath the ice shelf, can be found in Lambrecht and others (1999). Another purpose of the expedition was to extend knowledge of the regional distribution of accumulation rates and stable-isotope contents $\left({ }^{2} \mathrm{H},{ }^{18} \mathrm{O}\right)$ in surface firn. The distribution of these parameters on the Ronne Ice Shelf is already known to some extent from earlier investigations of snow pits and firn cores (Graf and others, 1994). Information was lacking between $78.5^{\circ}$ and $81.0^{\circ} \mathrm{S}$, in the southernmost part of the ice shelf and on the margin of the inland ice.

The traverse of the Filchner-V-Campaign (Jokat and Oerter, 1997) followed the ice flowline of the Foundation Ice Stream through site 6 of the British Antarctic Survey (BAS) and reached the relatively unexplored easternmost part of the Ronne Ice Shelf on the way to the grounding line (Fig. 1). With the help of an aircraft, two points at 480 and $1100 \mathrm{~m}$ a.s.l. were sampled on the inland ice. Over the total distance of $920 \mathrm{~km}$ the surface firn was sampled at 16 sites by means of shallow cores up to $12 \mathrm{~m}$ deep. The $10 \mathrm{~m}$ firn temperatures were measured using thermistor chains left behind in the boreholes for later remeasurements.

Depth profiles of the d.c. conductivity were established

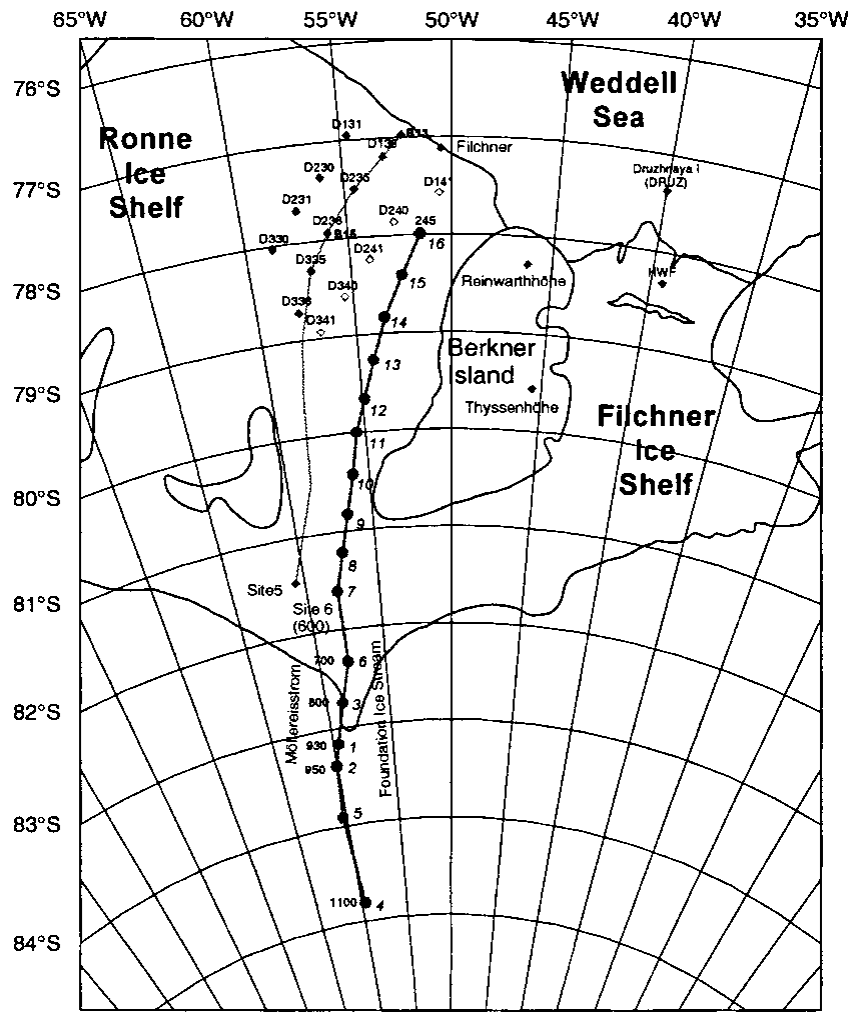

Fig. 1. Map of the Filchner-Ronne Ice Shelf with measuring locations of the Filchner-V-Campaign in 1994/95 ( ) and of former expeditions $(\bullet)$. The open symbols mark locations where only data from snow-pit studies are available. 
Table 1. Firn cores of the Filchner-V-Campaign 1994-95 (geodetic data are taken from fokat and Oerter, 1997)

\begin{tabular}{|c|c|c|c|c|c|c|c|c|c|c|c|c|c|c|}
\hline \multirow[t]{2}{*}{ Core } & \multirow[t]{2}{*}{ Site } & \multirow{2}{*}{$\begin{array}{c}\text { Date } \\
\mathrm{dd} / \mathrm{mm} / \mathrm{yy}\end{array}$} & \multirow[t]{2}{*}{$\begin{array}{l}\text { Longitude } \\
(W)\end{array}$} & \multirow[t]{2}{*}{$\begin{array}{l}\text { Latitude } \\
\text { (S) }\end{array}$} & \multirow{2}{*}{$\begin{array}{l}\text { Elevation } \\
\text { ma.s.l. }\end{array}$} & \multirow{2}{*}{\multicolumn{3}{|c|}{$\begin{array}{l}\text { Dating method } \\
{ }^{18} \mathrm{O}{ }^{3} \mathrm{H} \quad E C M\end{array}$}} & \multirow[t]{2}{*}{$\begin{array}{l}\text { Period covered } \\
\text { by the core }\end{array}$} & \multirow{2}{*}{$\begin{array}{l}\text { Firn density } \\
\qquad \begin{array}{l}(0-2 \mathrm{~m}) \\
\mathrm{g} \mathrm{cm}^{-3}\end{array}\end{array}$} & \multirow{2}{*}{$\begin{array}{c}\delta^{2} \mathrm{H} \\
\% 0\end{array}$} & \multirow{2}{*}{$\begin{array}{c}\delta^{18} \mathrm{O} \\
\%\end{array}$} & \multirow{2}{*}{$\begin{array}{c}d \\
\% o\end{array}$} & \multirow{2}{*}{$\begin{array}{c}A \\
\text { cm w.e. } \mathrm{a}^{-1}\end{array}$} \\
\hline & & & & & & & & & & & & & & \\
\hline GLB-16 & 245 & 22/02/95 & $51^{\circ} 32.00^{\prime}$ & $77^{\circ} 59.50^{\prime}$ & 65 & $\mathrm{x}$ & & & 1968-94 & 0.444 & & -26.63 & & 18.2 \\
\hline GLB-15 & 246 & $22 / 02 / 95$ & $52^{\circ} 28.40^{\prime}$ & $78^{\circ} 24.80^{\prime}$ & 68 & $\mathrm{x}$ & & & 1967-94 & 0.442 & & -27.39 & & 17.9 \\
\hline GLB-14 & 345 & $21 / 02 / 95$ & $53^{\circ} 28.40^{\prime}$ & $78^{\circ} 50.40^{\prime}$ & 71 & $\mathrm{x}$ & & & 1966-94 & 0.451 & & -28.22 & & 17.7 \\
\hline GLB-13 & & $21 / 02 / 95$ & $54^{\circ} 12.10^{\prime}$ & $79^{\circ} 16.10^{\prime}$ & 75 & $\mathrm{x}$ & & & 1965-94 & 0.449 & & -29.02 & & 15.4 \\
\hline GLB-12 & & 21/02/95 & $54^{\circ} 53.50^{\prime}$ & $79^{\circ} 40.20^{\prime}$ & 85 & $\mathrm{x}$ & & & & 0.439 & & -29.22 & & \\
\hline GLB-11 & 400 & 20/02/95 & $55^{\circ} 30.00^{\prime}$ & $80^{\circ} 00.00^{\prime}$ & 93 & $\mathrm{x}$ & & & & 0.425 & & -30.28 & & \\
\hline GLB-10 & & 20/02/95 & $55^{\circ} 58.80^{\prime}$ & $80^{\circ} 25.80^{\prime}$ & 104 & $\mathrm{x}$ & & $\mathrm{x}$ & $1953-94$ & 0.453 & & -30.60 & & 11.8 \\
\hline GLB-09 & 500 & $20 / 02 / 95$ & $56^{\circ} 35.30^{\prime}$ & $80^{\circ} 50.00^{\prime}$ & 107 & $\mathrm{x}$ & & & & & & -31.48 & & \\
\hline GLB-08 & & $19 / 02 / 95$ & $57^{\circ} 12.20^{\prime}$ & $81^{\circ} 13.10^{\prime}$ & 125 & $\mathrm{x}$ & & & & & & -31.55 & & \\
\hline GLB-07 & 600 & $19 / 02 / 95$ & $57^{\circ} 53.30^{\prime}$ & $81^{\circ} 36.30^{\prime}$ & 132 & $\mathrm{x}$ & $\mathrm{x}$ & & 1947-94 & 0.345 & -251.2 & -32.17 & 6.1 & 9.8 \\
\hline GLB-06 & 700 & 18/02/95 & $57^{\circ} 49.60^{\prime}$ & $82^{\circ} 20.10^{\prime}$ & 143 & $\mathrm{x}$ & & $\mathrm{x}$ & 1946-94 & 0.447 & & -32.80 & & 10.1 \\
\hline GLB-03 & 800 & $11 / 02 / 95$ & $58^{\circ} 41.50^{\prime}$ & $82^{\circ} 45.00^{\prime}$ & 145 & $\mathrm{x}$ & & $\mathrm{x}$ & $1946-94$ & 0.445 & & -33.32 & & 9.0 \\
\hline GLB-01 & 930 & 03/02/95 & $59^{\circ} 34.50^{\prime}$ & $83^{\circ} 10.00^{\prime}$ & 163 & $\mathrm{x}$ & $\mathrm{x}$ & $\mathrm{x}$ & 1949-94 & 0.430 & -269.4 & -34.53 & 6.8 & 9.9 \\
\hline GLB-02 & 950 & 09/02/95 & $60^{\circ} 03.80^{\prime}$ & $83^{\circ} 23.10^{\prime}$ & 185 & $\mathrm{x}$ & & & & & & -35.22 & & \\
\hline GLB-05 & 1000 & $17 / 02 / 95$ & $60^{\circ} 21.60^{\prime}$ & $83^{\circ} 55.10^{\prime}$ & 482 & $\mathrm{x}$ & & & & & & -35.85 & & \\
\hline GLB-04 & 1100 & $17 / 02 / 95$ & $59^{\circ} 38.10^{\prime}$ & $84^{\circ} 49.10^{\prime}$ & 1191 & $\mathrm{x}$ & $\mathrm{x}$ & & 1959-94 & 0.505 & -313 & -40.36 & 9.8 & 17.1 \\
\hline
\end{tabular}

Notes: Reliable firn temperatures at $10 \mathrm{~m}$ depth are available only at sites 930 and $950\left(-30.0^{\circ}\right.$ and $-30.2^{\circ} \mathrm{C}$, respectively). At the other sites the measurement time in 1995 was too short and remeasurement is required.

using the electrical conductivity method (ECM) introduced by Hammer (1980), and the cores were subsampled for isotope analysis. ${ }^{18} \mathrm{O}$ contents of all cores were determined and the ${ }^{2} \mathrm{H}$ and ${ }^{3} \mathrm{H}$ contents of three of the 16 cores were analyzed. The isotope signatures of surface snow and of ice-shelf cores allow us to elucidate the structure of the ice shelf and to trace the origin of the ice.

\section{ANALYSES}

The cores were dated using stratigraphical information on several parameters (Table 1). The dating of firn cores from near-coastal areas with relatively high accumulation rates is based on $\delta^{18} \mathrm{O}$ profiles (Fig. 2). They were measured using a depth resolution of about $35 \mathrm{~mm}$ to ensure that seasonal variations were detected. South of Berkner Island the dating was based on profiles of artificial tritium. Strong katabatic winds have reworked the surface snow in this area and disturbed the stratigraphic sequence. So far, only four of the 16 ECM profiles have been stratigraphically evaluated. At three sites the ECM profile was used to date the firn. At one of these locations the stratigraphic significance of the ECM profile could be assessed comparing it with stratigraphic information on the ${ }^{3} \mathrm{H}$ profile. Six of the 16 firn cores have not yet been dated.

The tritium dating is based on depth profiles of artificial tritium that was released into the atmosphere of the Northern Hemisphere during the nuclear weapon test series (Carter and Moghissi, 1977) and reached the Southern Hemisphere via stratospheric exchange with a delay of approximately 1 year (e.g. Jouzel and others, 1979). The ${ }^{3} \mathrm{H}$ concentration in the Southern Hemispheric precipitation, generally lower then in the Northern Hemisphere, varies with the amount of precipitation. But at all stations the time series of artificial ${ }^{3} \mathrm{H}$ concentrations in precipitation are quite similar, as indicated by the data from stations of the
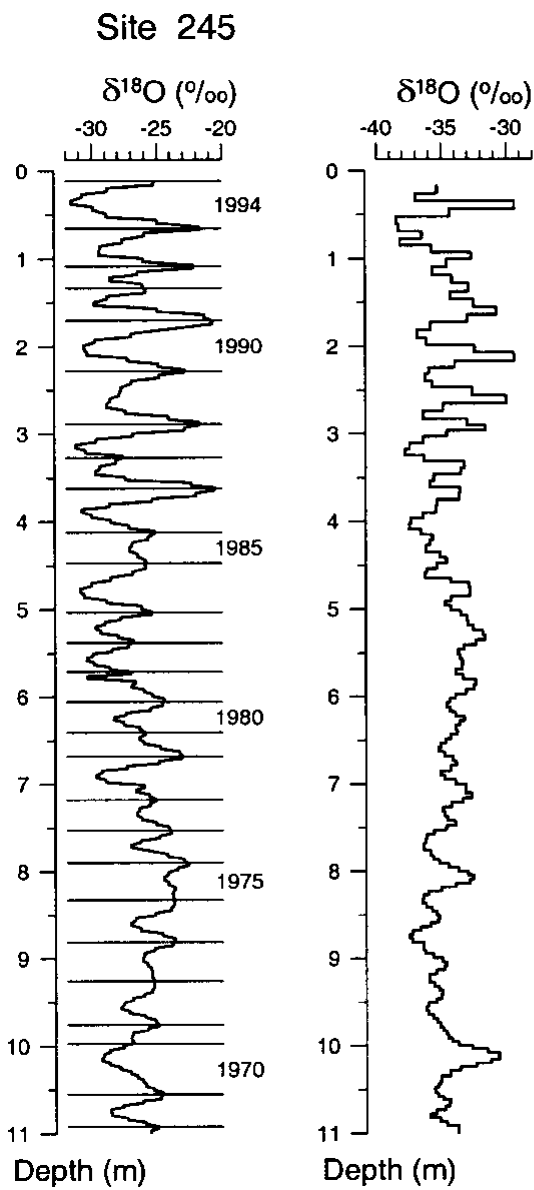

Site 930

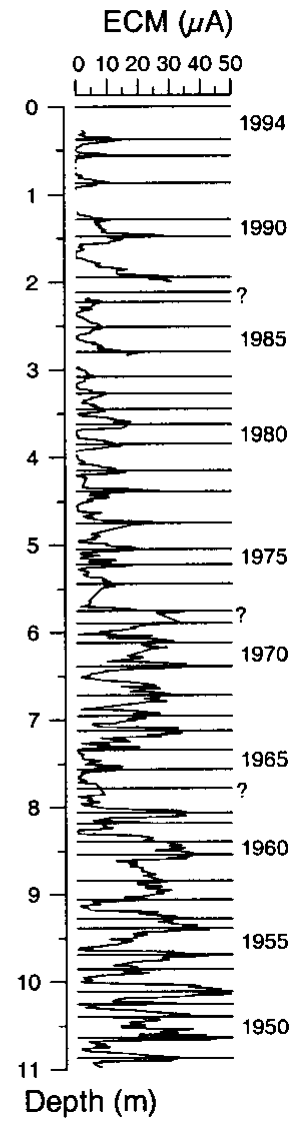

Fig. 2. Depth profiles of ${ }^{18} \mathrm{O}$ content and firn bulk conductivity (ECM). Summer horizons are indicated. At point 930, only the ECM profile contains valuable stratigraphic information on the annual layering. Boundaries that are justified only knowing the firn age in the $8 \mathrm{~m}$ depth from the ${ }^{3} \mathrm{H}$ dating are indicated by question marks. 
Site 1100

(GLB-04)

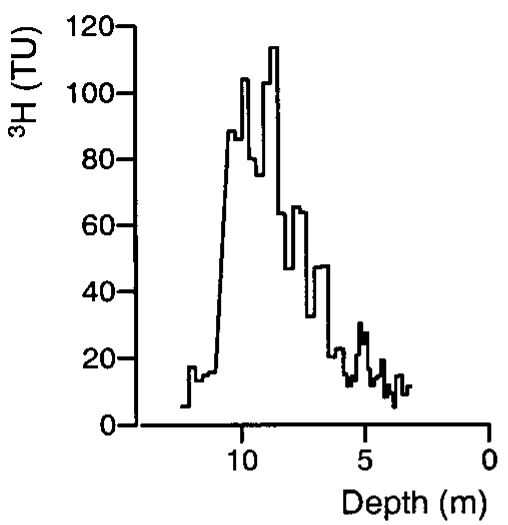

Site 930

(GLB-01)
Site 600

(GLB-07)
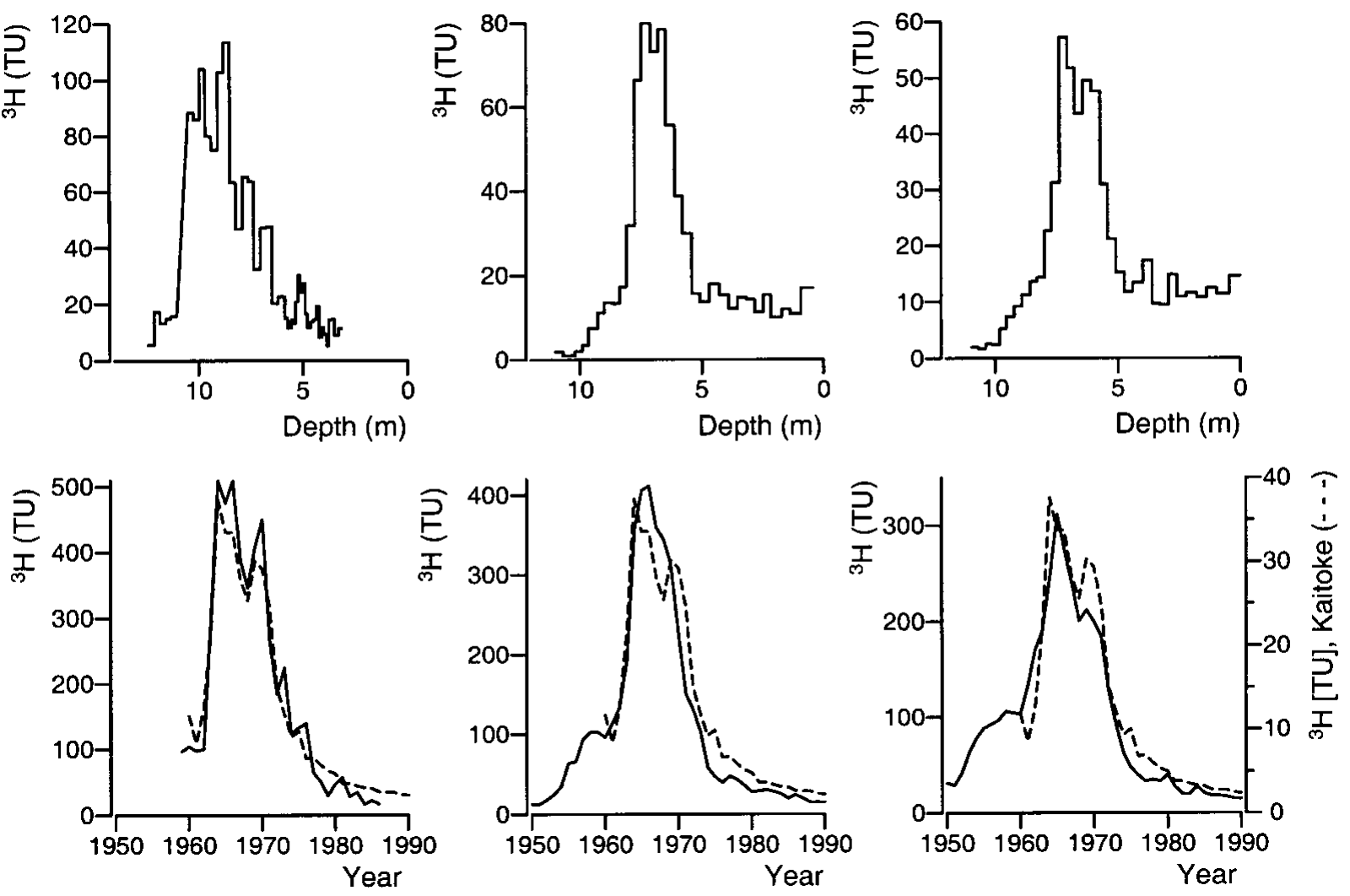

Fig. 3. Time series of the ${ }^{3} \mathrm{H}$ content in the precipitation at three sites 1100,930 and 600 deduced from the ${ }^{3} \mathrm{H}$ depth profiles. Depth profiles were transformed to time series by using accumulation rates of 17,10 and $10 \mathrm{~cm} w . e . a^{-1}$, respectively. For comparison the time series of the ${ }^{3} \mathrm{H}$ content in precipitation at Kaitoke, New Zealand, are shown (dashed line). TU, tritium units.

International Atomic Energy Agency (IAEA, 1992; http:// www.iaea.org/programs/ri/gnip/gnipmain.htm). This means that the typical distribution at Kaitoke, New Zealand, or on the Falkland Islands must also be preserved in the snow cover of the Ronne Ice Shelf and can be used to date firn cores. The best depth-time relationship (determined by trial and error at each site) is the one that transforms the measured depth profiles to time series most similar to the one at Kaitoke. The inherent assumption is that the accumulation rate at the site has been constant over the last few decades.

At sites 600 (GLB-07), 930 (GLB-01) and 1100 (GLB-04) the depth profiles were transformed to time series which were quite similar to that at Kaitoke (Fig. 3) with accumulation rates of 9.8, 9.9 and $17.1 \mathrm{~cm}$ w.e. $\mathrm{a}^{-1}$ The dating accuracy is 1 year or $3 \%$. A dating error of 1 year can easily be observed when comparing the calculated and reference time series. This accuracy could be achieved because the cores contain all precipitation important for the inventory of artificial tritium, back to the late 1950s. The dating error and the error in the density determination (about $5 \%$ ) limit the accuracy of the deduced accumulation rates to 6 $8 \%$. Near-surface firn can be dated back to the mid-1950s most accurately by the ${ }^{3} \mathrm{H}$ method, which requires the adjustment of only one parameter, the mean accumulation rate over the last 35 years. It is not necessary to assess the stratigraphic significance of signals in the measuring profiles, a serious problem, especially in low-accumulation-rate areas when using ECM or ${ }^{18} \mathrm{O}$ profiles.

It is well known that the bulk conductivity of the firn de-

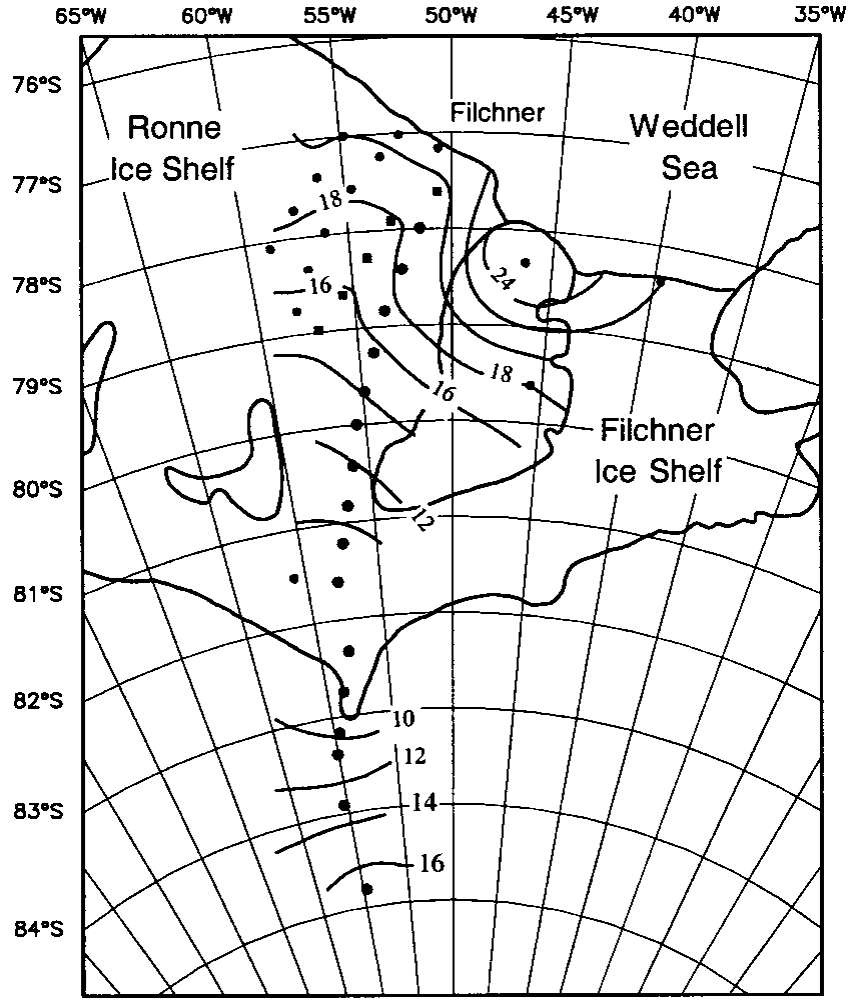

Fig. 4. Distribution of the snow-accumulation rates in the eastern part of the Ronne Ice Shelf. Isoline values in cm w.e. $a^{-1}$. 


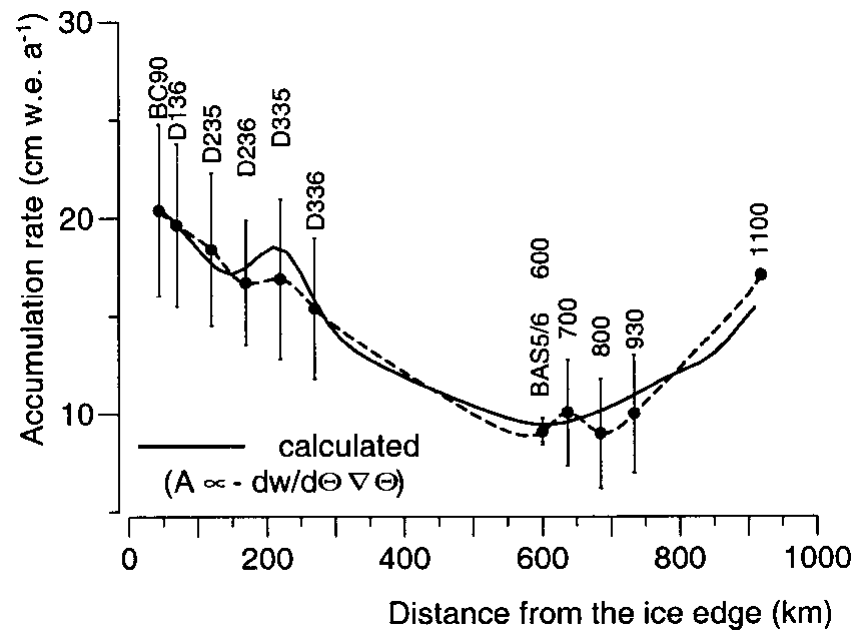

Fig. 5. Accumulation rates in the eastern part of the Ronne Ice Shelf along flowline I (Möllereisstrom) towards site 5 and further south along flowline II (Foundation Ice Stream). The vertical bars indicate the interannual scatter. At sites 600 and 1100, only mean accumulation rates are known.

pends on its chemical composition. Acids like $\mathrm{H}_{2} \mathrm{SO}_{4}$ increase, whereas sea salt $(\mathrm{NaCl})$ suppresses, the bulk conductivity. The concentration of non-sea-salt sulphate shows a clear summer maximum (Wagenbach and others, 1988). During fall and spring, $\mathrm{NaCl}$ dominates the chemistry of the aerosols. Therefore, a clear seasonal signal is expected and generally found in the ECM profiles. At site 930 (core GLB-01) the stratigraphic interpretation of the ECM profile over most of the core is straightforward. From the ${ }^{3} \mathrm{H}$ dating it can be inferred that only three layers fail to be displayed in the profile down to $8 \mathrm{~m}$ depth (Fig. 2). These three layers are necessary to reconcile the ECM and the ${ }^{3} \mathrm{H}$ dating. As a result, the ECM dating at site 930 is accurate to 3 years, corresponding to $10 \%$, which is

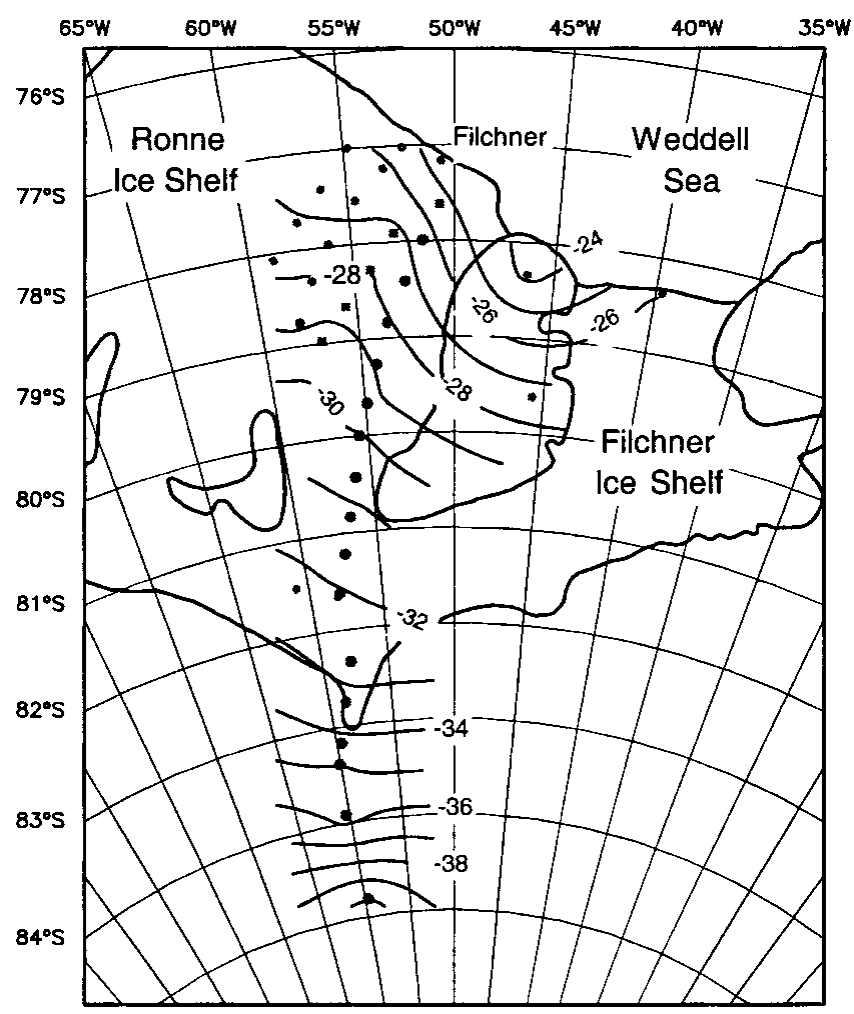

Fig. 6. Distribution of the ${ }^{18} \mathrm{O}$ content of snow in the eastern part of the Ronne Ice Shelf. Isoline values in \%o. comparatively good in respect to the low accumulation rates at this site. The ECM profiles and the dating of cores GLB-03, GLB-06 and GLB-10 are assumed to be of the same quality, because the cores were drilled in areas with similar accumulation rates. At the drilling site of core GLB-10 the accumulation rates are even higher than at site 930 .

\section{DISTRIBUTION OF THE ACGUMULATION RATES AND STABLE-ISOTOPE CONTENTS}

The accumulation rates in the eastern part of the Ronne Ice Shelf decrease between the ice edge and BAS sites 5 and 6 from 20 to $9 \mathrm{~cm}$ w.e. $\mathrm{a}^{-1}$, reach values of about $10 \mathrm{~cm}$ w.e. $\mathrm{a}^{-1}$ at the grounding line and rise to $17 \mathrm{~cm}$ w.e. $\mathrm{a}^{-1}$ at site 1100 (Fig. 4).

The spatial distribution of the accumulation rate canbe calculated from the measured $10 \mathrm{~m}$ firn temperature, $\theta$. The accumulation rate, $a$, is assumed to be proportional to the decrease of the mixing ratio with temperature $(\mathrm{d} w / \mathrm{d} \theta, w=$ mixing ratio) multiplied by the temperature gradient $(\mathrm{d} \theta / \mathrm{d} x)$. The
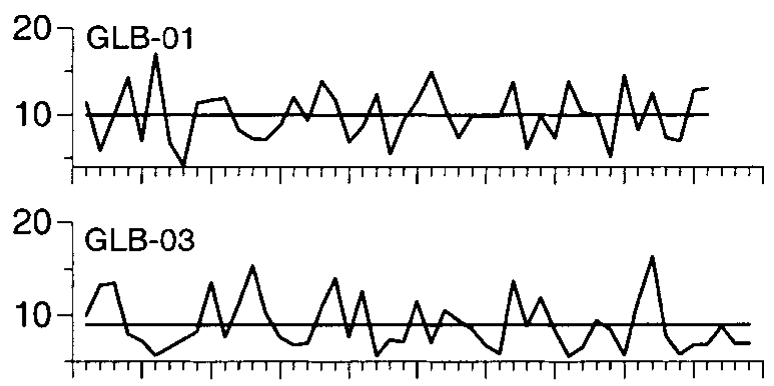

207 GLB-06

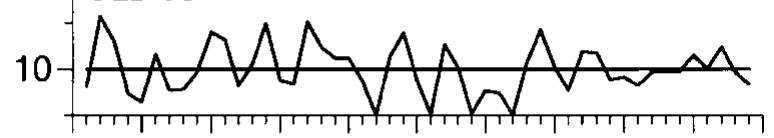

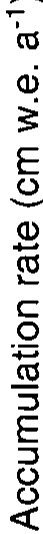

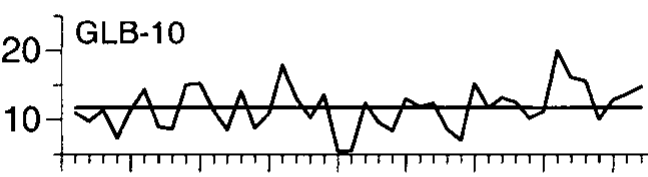

过
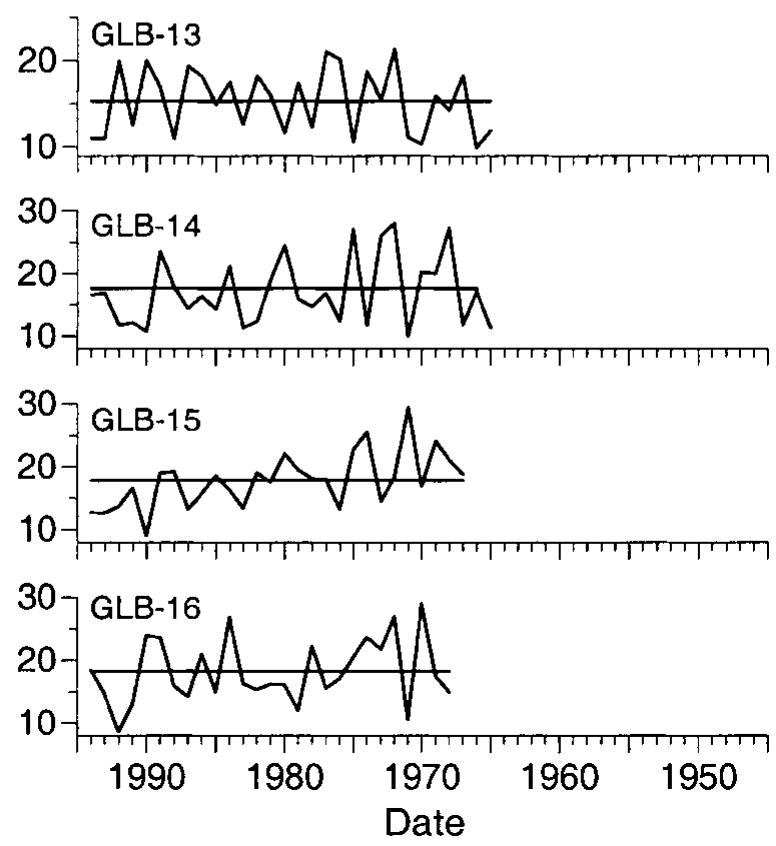

Fig. 7. Time series of accumulation rate at eight sites covering the entire eastern Ronne Ice Shelffrom the ice edge in the north to the grounding line in the south. The horizontal lines indicate mean values. 

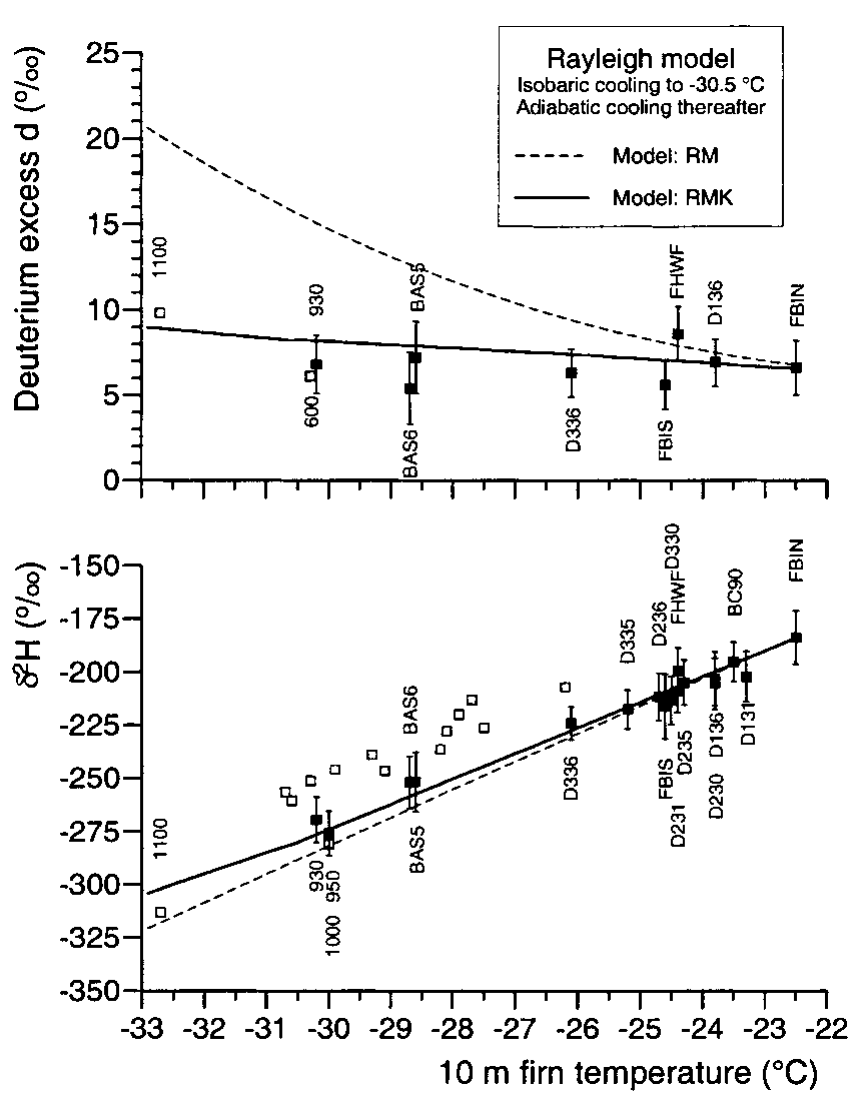

Fig. 8. Relationship between the $\delta^{2} \mathrm{H}$ values and the $10 \mathrm{~m}$ firn temperature in the eastern part of the Ronne Ice Shelf. Data from earlier investigations (Graf and others, 1994) are also included. The open symbols mark those locations where temperature data are questionable. At some sites, only $\delta^{18} \mathrm{O}$ values are available; they are converted to $\delta^{2} \mathrm{H}$ values using $\delta^{2} \mathrm{H}=8 \times \delta^{18} \mathrm{O}+8$ for illustration. Also shown are ${ }^{2} \mathrm{H}$ contents calculated according to the Rayleigh model, including the isotopic kinetic effect (RMK) and excluding the kinetic effect (RM).

constant of proportionality which accounts, for example, for the thickness of the air mass, was chosen to adjust the calculated and measured accumulation at one point. The simulated accumulation rates agree well with the measured distribution, despite the simplifying assumptions involved (Fig. 5).

The spatial distribution of the ${ }^{18} \mathrm{O}$ content of the near-surface snow is governed by the temperature field. Because of the different temperature gradients, the $\delta^{18} \mathrm{O}$ ratio decreases with a horizontal gradient of $1.3 \%(100 \mathrm{~km})^{-1}$ across the ice shelf and $3.2 \%$ o $(100 \mathrm{~km})^{-1}$ ascending the inland ice (Fig. 6).

The firn cores cover a time-span of 27 years in the northern and 49 years in the southern part of the ice shelf. The ${ }^{18} \mathrm{O}$ content and the annual layering provide information on changes of temperature and precipitation amount, respectively. In this period, dramatic temperature changes were observed at the Antarctic Peninsula (Peel and others, 1988). This seems not to be the case in the more southern and continental area of the Ronne Ice Shelf, where no statistically significant trends in the time series either of the ${ }^{18} \mathrm{O}$ content or of the accumulation rates could be found (Fig. 7).

\section{THE ISOTOPE-TEMPERATURE RELATIONSHIP}

The isotopic values of the near-surface layers are closely related to the $10 \mathrm{~m}$ firn temperature (Fig. 8). The data in Figure 7 are grouped along two lines most probably caused by problems in the measurement of the $10 \mathrm{~m}$ firn temperature. The ${ }^{2} \mathrm{H}$ contents of the firn cores drilled in 1990, and the $10 \mathrm{~m}$ temperatures measured the same year follow a regression line very closely. In contrast, the data from the $1995 \mathrm{ex}-$ pedition show a larger scatter: four data pairs from sites 930, 950, 1000 and 1100 fit in the data of the year 1990; the others follow a regression line, which is almost parallel to the first one. Similar discrepancies were observed comparing data from 1990 with those of 1984. It is believed that this shift in the regression lines by $20 \%$ is not real, but is more likely due to the calibration of the thermistors or the measuring procedure. At sites on the traverse, the measuring times may have been simply too short for the thermistors to completely adjust to the surrounding firn temperature. This was only possible at sites around the base camp, where measurements could be repeated on several days. The ${ }^{2} \mathrm{H}$ and temperature values at these sites fit into the known $\delta-\theta$ relationship of $\mathrm{d} \delta^{2} \mathrm{H} / \mathrm{d} \theta=10.3 \pm 0.6 \% \mathrm{~K}^{-1}$ (Graf and others, 1994).

The Rayleigh model explains the decrease of the ${ }^{2} \mathrm{H}$ and ${ }^{18} \mathrm{O}$ contents with temperature, assuming that during the formation of precipitation the isotope fractionation between water vapour and condensate is governed not only by equilibrium but also by kinetic processes (Jouzel and Merlivat, 1984). Kinetic processes counterbalance the depletion in the heavier isotopes and avoid an unrealistic increase of the deuterium excess values (Fig. 8).

\section{SOME GLACIOLOGICAL IMPLICATIONS}

A first result of the investigation is that the surface accumulation rates at the grounding line $\left(0.1 \mathrm{~m}\right.$ w.e. $\left.\mathrm{a}^{-1}\right)$ are two orders of magnitude less than the melting rates beneath the ice shelf (in the order of 5-10 $\mathrm{m} \mathrm{a}^{-1}$, Lambrecht and others, 1999).

Beneath the Ronne Ice Shelf a layer of saline ice was postulated to explain the surface elevation of the ice shelf which otherwise would not be in isostatic equilibrium (Thyssen, 1988). Two ice cores B13 and B15 from this area confirmed this (Oerter and others, 1992). Under the central Ronne Ice Shelf, ice of marine origin is up to $350 \mathrm{~m}$ thick. The ${ }^{18} \mathrm{O}$ contents indicate that the ice down to $152 \mathrm{~m}$ is of meteoric origin and that the catchment area of the cores extends far to the south. How far can now be answered by stable-isotope contents of firn and ice. In both cores, very low $\delta^{18} \mathrm{O}$ values of $-40 \%$ were found immediately above the marine ice (Fig. 9c). In surface snow the same isotope signature was measured at the southernmost site (Fig. 9a). This indicates that the ice immediately above the marine layer originates from the inland ice margin at $1100 \mathrm{~m}$ a.s.l. and $930 \mathrm{~km}$ from the ice edge.

Ice formed from snow deposited further south was not found in the ice-shelf cores. This ice has been melted away between the grounding line and $80^{\circ} \mathrm{S}$ where accretion of marine ice starts. The deepest-placed meteoric ice is sealed by the marine ice and moves to the ice front along the boundary surface between the meteoric and marine ice. This ice takes a deep path as it enters the channel between Berkner Island and Henry Ice Rise and rises at a fast rate after passing the channel (Fig. 9b), as deduced from the mapping of the boundary surface (Thyssen, 1988). Using the particle-path model of Thomas (1973), vertical strain rates were estimated along the flowline which passes site 5 . The known or interpolated ice velocities (Möller and Ritter, 1988) and accumulation rates were used, as well as the depth of the trajectory (the depth of the boundary surface 
a) Regional distribution of ${ }^{18} \mathrm{O}$ content

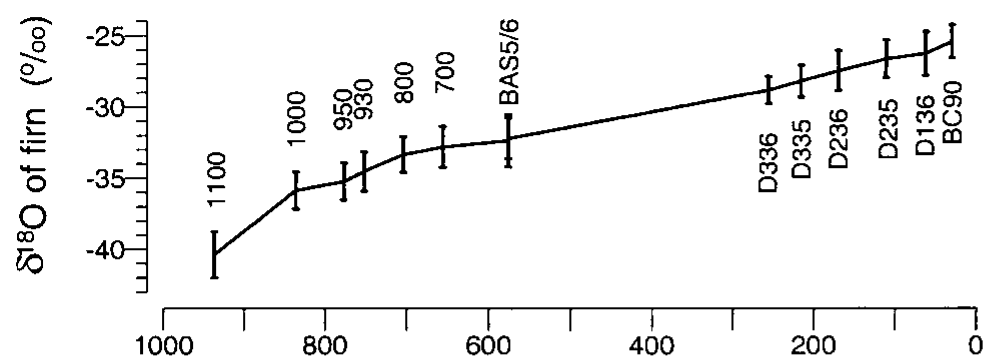

b) Particle paths in the Ronne Ice Shelf

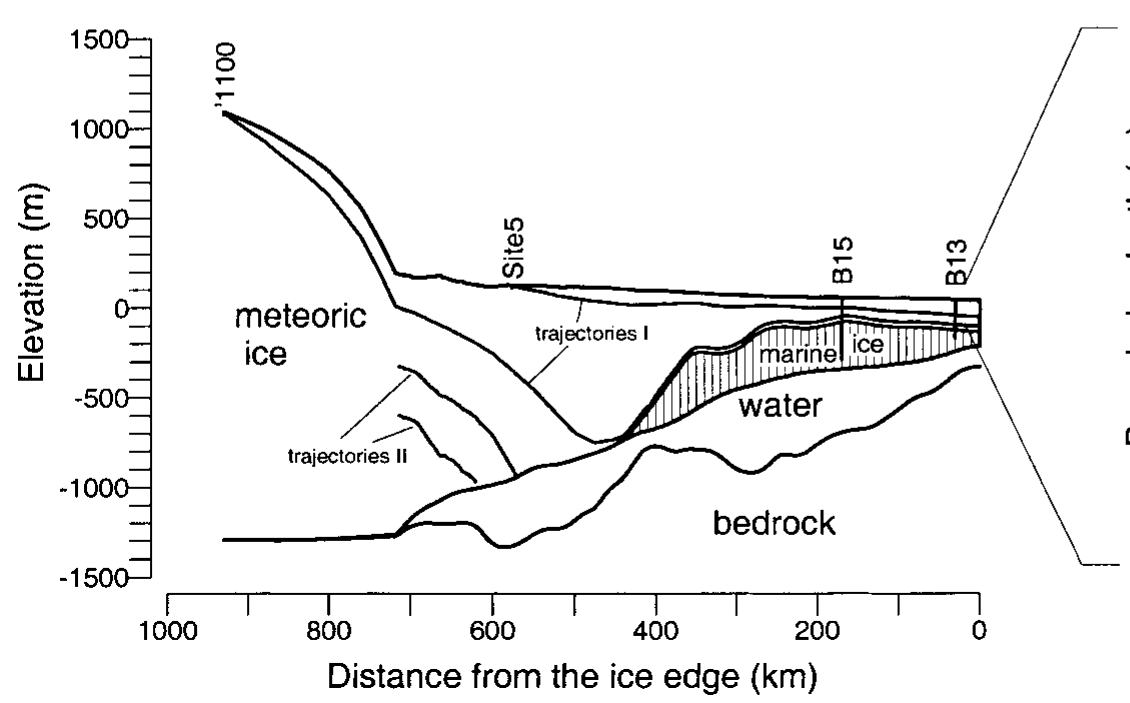

c) Depth profile of ${ }^{18} \mathrm{O}$ content at $\mathrm{B} 13$

Fig. 9. The Ronne Ice Shelfflowline I ( Möllereisstrom, see Fig. 1). Particle trajectories marked by I can be followed from the snow surface to the ice front. Those marked by II end beneath the ice shelf due to high melting rates. The isotopic signatures of surface snow can be found in the depth profiles of ice-shelf cores. The regional distribution of the ${ }^{18} \mathrm{O}$ content in surface snow are shown along flowline I (Möllereisstrom) towards site 5 and further south along flowline II (Foundation Ice Stream) towards site 1100. As an example of a depth profile the $\delta^{18} \mathrm{O}$ profile of ice-shelf core B13 is shown (below $152 \mathrm{~m}$ depth the ice shelf consists of marine ice).

along the flowline). According to the calculations, the vertical strain rates south of Berkner Island must be of the order of $1.5 \times 10^{-3} \mathrm{a}^{-1}$, and further north where the channel is widening, strain rates down to $-5 \times 10^{-3} \mathrm{a}^{-1}$ are necessary to bring the trajectory to the observed height. The estimated vertical strain rates are in the range of values deduced from geodetic surface measurements as far as these are known, i.e. north of $79^{\circ} \mathrm{S}$ and at site 5. The large stress together with the additional buoyancy forces caused by the accretion of marine ice may cause the so-called disturbed ice north and northeast of Henry Ice Rise shown in the glaciological map of the Filchner-Ronne Ice Shelf (IfAG, 1987).

\section{ACKNOWLEDGEMENT}

Financial support for this work from the Deutsche Forschungsgemeinschaft (DFG Re 762/2 and OE 130/2) is gratefully acknowledged. This is Alfred Wegener Institute publication No. 1474.

\section{REFERENCES}

Carter, M.W. and A. A. Moghissi. 1977. Three decades of nuclear testing. Health Phys., 33, 55-71.

Graf, W. and 6 others. 1994. Snow-accumulation rates and isotopic content $\left({ }^{2} \mathrm{H},{ }^{3} \mathrm{H}\right)$ of near-surface firn from the Filchner-Ronne Ice Shelf, Antarctica. Ann. Glaciol., 20, 121-128.
Hammer, C. U. 1980. Acidity of polar ice cores in relation to absolute dating, past volcanism, and radio-echoes. F. Glaciol., 25(93), 359-372.

Institut für Angewandte Geodäsie (IfAG). 1987. Filchner-Ronne-Schelfeis. Institut für Angewandte Geodäsie, Frankfurt am Main. (Topographische Karte und Satellitenbildkarte Glaciological Map, scale 1:2 000000.

International Atomic Energy Agency (IAEA). 1992. Statistical treatment of data on environmental isotopes in precipitation. Vienna, International Atomic Energy Agency. (IAEA Technical Report Series 331.)

Jokat, H. and H. Oerter. eds. 1997. Die Expedition ANTARKTIS-XII mit FS Polarstern 1995, Bericht vom Fahrtabschnitt ANT-XII/3. Ber. Polarforsch. 219.

Jouzel, J. and L. Merlivat. 1984. Deuterium and oxygen 18 in precipitation: modeling of the isotopic effect during snow formation. 7. Geophys. Res., 89(D7), 11,749-11,757.

Jouzel, J., L. Merlivat, J.R. Petit and C. Lorius. 1983. Climatic information over the last century deduced from a detailed isotopic record in the South Pole snow. 7. Geophys. Res., 88(C4), 2693-2703.

Lambrecht, A., C. Mayer, H. Oerter and U. Nixdorf. 1999. Investigations of the mass balance of the southeastern Ronne Ice Shelf, Antarctica. Ann. Glaciol., 29 (see paper in this volume).

Möller, D. and B. Ritter. 1988. Glacial geodetic contributions to the mass balance and dynamics of ice shelves. Ann. Glaciol., 11, 89-94.

Oerter, H. and 6 others. 1992. Evidence for basal marine ice in the FilchnerRonne Ice Shelf. Nature, 358(6385), 399-401.

Peel, D. A., R. Mulvaney and B. M. Davison. 1988. Stable-isotope/air-temperature relationships in ice cores from Dolleman Island and the Palmer Land plateau, Antarctic Peninsula. Ann. Glaciol., 10, 130-136.

Thomas, R. H. 1973. The dynamics of the Brunt Ice Shelf, Coats Land, Antarctica. Br. Antarct. Surv. Sci. Rep. 79.

Thyssen, F. 1988. Special aspects of the central part of Filchner-Ronne Ice Shelf, Antarctica. Ann. Glaciol., 11, 173-179.

Wagenbach, D., U. Görlach, K. Moser and K. O. Münnich. 1988. Coastal Antarctic aerosol: the seasonal pattern of its chemical composition. Tellus, 40B (5), 426-436. 